\title{
Review of Modern Vehicle Powertrains and Their Modelling and Simulation in MATLAB/Simulink
}

\author{
A. SZÁNTó ${ }^{1}$, G. Á. SZIKI ${ }^{2}$ \\ 1Faculty of Engineering of the University of Debrecen, szanto.attila93@gmail.com \\ 2Faculty of Engineering of the University of Debrecen, szikig@eng.unideb.hu
}

\begin{abstract}
Thanks to technological advances and environmental standards, as well as changing usage patterns, road vehicles are constantly developing. Electric and hybrid vehicles are playing an increasingly important role in today's road transport. The most significant changes are probably in the powertrain of vehicles. The efficiency of internal combustion engines increases while their emissions continue to decline. In addition, high performance electric motors, batteries and even fuel cells play an increasingly important role in hybrid and electric vehicles. In this publication, we review the drive systems of current modern vehicles and the types and characteristics of their major components. We also review the available models and computer programs for their simulation, focusing mainly on MATLAB/Simulink applications. Based on this, we can develop our own models and simulation programs which will help us to perform different driving dynamics simulations and to compare the performance, dynamic and energetic characteristics of these powertrains and their components to each other.
\end{abstract}

\section{Introduction}

Road vehicles have been constantly developing over the last decades. This is particularly true of one of the base parts of the vehicles, namely the powertrain. The reason for this development is the utilization of the opportunities provided by the developing technology, which can be used to satisfy the ever changing needs of users. On the other hand, there are various legal/statutory regulations aimed at improving traffic safety and reducing air pollution. In addition to vehicles powered by a conventional internal combustion engine, nowadays, different alternative-driven vehicles are playing an increasingly important role in road transport. Of the various alternative-driven types the most prominent are electric and hybrid electric drives, owing to the rapid development of modern batteries, and electrical and hybrid systems. The range of electric vehicles available today or soon to be developed is more than $500 \mathrm{~km}$ in many cases, while charging time can be reduced to $10-15$ minutes by means of a suitable charger. As a result, these vehicles are becoming more usable, which is constantly increasing sales while reducing production costs.

At the Faculty of Engineering of Debrecen University, we have long been engaged in the development and production of various alternative-driven (primarily electric and pneumatic) prototype vehicles and powertrains. For a more efficient racing, we have developed our own vehicle dynamics simulation program, which enables to perform vehicle dynamic simulations for each race. This allows us to optimize the technical parameters of the vehicle and powertrain for competition tasks. 
In the frame of the Thematic Excellence Programme of the Ministry for Innovation and Technology in Hungary (ED_18-1-2019-0028), within the framework of the (Automotive Industry) thematic programme of the University of Debrecen we would like to extend this program for the simulation of road vehicles as well as powertrains. To do so, first of all, it is important to review the current state-ofthe-art vehicle drives, their structure, the operation and types of their main components. In addition, we summarize the literature on modelling and simulation of each component which can be used to build our own simulation program.

\section{Review of electric powertrains}

Electric vehicles of high energy efficiency, low maintenance cost and pollution free operation, are offering a great alternative to popular conventional Internal Combustion (IC) engine vehicles. Also, with the advancement in technology, electric vehicle manufacturers can overcome the traditional drawbacks of electric vehicles, making them more and more suitable for modern day transportation [1]. As a result, nowadays there are several types of electric motors applied in electric or hybrid vehicles in every day road transport. In the following, we review the scientific literature about the above motor types, together with their characteristic parameters and graphs, and also the models and programs applied to simulate them in MATLAB/Simulink. Additionally, we review the different types of batteries and fuel cells, which are used to power them. Finally, several types of electric motor drives and their features in applications for electric (EV) and hybrid electric vehicles (HEV) are reviewed.

\subsection{Electric motors}

In reference [1] different types of electric motors such as DC Brushed motor (BDC), DC Brushless motor (BLDC), Induction (Asynchronous) motor (IM), Synchronous motor (SM), Switched Reluctance motor (SRM) are compared on the basis of certain parameters which should be considered for selecting a particular motor type for electric vehicle application. Comparison is tabulated for some parameters. Also, characteristic graphs of different motors are included at some points. In reference [2] a critical review of the drivelines in all-electric vehicles (EVs) is presented. The motor topologies that are the best candidates to be used in EVs are also presented. The advantages and disadvantages of each electric motor type are discussed from a system perspective. A survey of the electric motors used in commercial EVs is presented. Reference [3] reviews several types of electric motor drives and their features in applications for electric (EV) and hybrid electric vehicles (HEV). Basic configurations for EVs and HEVs are introduced. Then the discussion of diverse types of electric motors including DC, IM, PM, SRM, and SynRM machines is presented. In the following, a systematic review about the modelling and simulation of the different types of electric motors - applied in electric vehicles - are presented.

DC Brushed motor (BDC)

In reference [4] the modelling of an electric utility vehicle powered by a separately wound DC motor is discussed. The model using bond-graph techniques to develop a causal model of the vehicle and development of the appropriate feed-forward and feed-back controllers is required for route following. The causal model performance is compared to a PSAT model of the same electric vehicle, 
which uses a motor torque-speed curve. Reference [5] deals with the mathematical modelling of a series wound DC motor, where magnetic nonlinearities play a significant role. Three different models are presented: a magnetically linear dynamic model and two different types of magnetically nonlinear dynamic models. Each model has been evaluated on the basis of results obtained by simulations and results of measurements conducted on a tested motor.

The objective of reference [6] is to assess the use of a series DC motor in an electric car with its rotation speed controller, and to evaluate its performances in different running cases of the electric car applying different loads. The mathematical equations model of a series DC motor and an electronic inverter in dynamic state with reference frame $d-q$ were considered. A computer model of these equations was implemented using MATLAB/SIMPOWER facilities obtaining a complete model for motor and controller.

\section{Brushless motor (BLDC)}

In reference [7] a study about the modelling and simulation of a BLDC motor using MATLAB as tool is presented. The research explores the performance of a three-phase permanent magnet (PM) motor which is operating as a brushless DC (BLDC) motor. In reference [8] the modelling and simulation of a three-phase brushless DC motor (BLDCM) with MATLAB/Simulink is presented. In reference [9] a three-phase brushless DC motor model is designed and tested under trapezoidal back electromotive force using MATLAB software. On the other hand, parameters such as Back EMF, current, speed and torque are evaluated for the designed models of the BLDC motor. In reference [10], based on the mathematical model of the Brushless DC motor (BLDCM), a novel method of modelling and simulation for the speed control system of BLDCM with Kalman Filter is presented.

Induction (Asynchronous) motor (IM)

In reference [11] all types of AC drives and their control in common use today is discussed. These include induction-motor drives, permanent magnet AC drives and switched-reluctance drives. Encoderless operation of induction-motor drives is also discussed. In reference [12] a generalized model of the three-phase induction motor and its computer simulation using MATLAB/SIMULINK are presented. Constructional details of various sub-models for the induction motor are given and their implementation in SIMULINK is outlined. Direct-online starting of a $7.5-\mathrm{kW}$ induction motor is studied using the simulation model developed. In reference [13] a step by step Simulink implementation of an induction machine using dq0 axis transformations of the stator and rotor variables in the arbitrary reference frame are available. For this purpose, the relevant equations are stated the beginning, and then a generalized model of a three-phase induction motor is developed and implemented in an easy to follow way.

\section{Synchronous motor (SM)}

In Reference [14] Section 1 deals with the introduction of a Permanent Magnet Synchronous motor (PMSM) and how it is evolved from other synchronous motors. Section 2 briefly discusses the types of PMSM. Section 3 investigates the assumptions in PMSM for modelling PMSM and it derives the equivalent circuit of PMSM. In Section 4, a permanent magnet synchronous motor drive system is briefly discussed with each block in the systems described. Section 5 reveals the control techniques of 
PMSM like scalar control, vector control and simulation of PMSM driven by field-oriented control using fuzzy logic control with space vector modulation to minimize torque ripples. PMSM control with and without rotor position sensors along with different control techniques for controlling various parameters of PMSM for different applications is presented in Section 6. Reference [15] proposes two simulation dynamic models for AC Interior Permanent Magnet Synchronous Motor (IPMSM), and AC Surface Permanent Magnet Synchronous Motor (SPMSM) with the aid of MATLAB - Simulink. The modelling procedures are described and simulation results are presented. Reference [16] presents an implementation of a time efficient powertrain model of electric two-wheelers (e-scooters). The model consists of an electric motor, power electronics and a Li-ion battery with aging prediction. As a motor model a Permanent Magnet Synchronous Motor design is used. An empirical aging model for a Lithium Manganese Oxide cell is presented, which is based on aging measurements. Together, the models provide an opportunity to evaluate the long-term cell aging behaviour under realistic drive cycles taking motor effects into account.

Switched Reluctance motor (SRM)

In reference [17] Chapter 3 deals with electrical drives of induction machines. After a short introduction concerning basic construction variants and general problems of modelling induction motor drives, mathematical models are developed on the basis of the previously introduced Lagrange's method. Chapter 4 deals with the properties and control of brushless DC motor drives with a permanent magnet excitation (BLDC, PMDC). In the first part, characteristics of contemporary permanent magnets (PM) that are used in electric motors are presented along with the simplified ways of their modelling. Chapter 5 is devoted to Switched Reluctance Motor (SRM) drives. Firstly, nonlinear magnetizing curves of SRM are presented and their importance for motor operation is discussed. The model presented in the chapter takes these nonlinear characteristics into account depending on phase current and rotor position angle, but ignores mutual magnetization of phases. In reference [18] the mathematical model of SRM motor and its working principle are considered. In addition to this, the Simulink model of switched reluctance motor is designed and tested through MATLAB/Simulink software. The parameters such as current, flux, inductance, speed and torque are represented graphically. In references [19] a model for switched reluctance motor is performed by MATLAB/Simulink. The initial data for SRM modelling is the calculation results of magnetic system run by finite elements method. In reference [20] the simulation of speed control techniques of switched reluctance motors (SRM) using Matlab Simulink are presented. Three controllers: P, PI, and PID were used for simulation and after proper tuning using trial and error, the PID controller gave the best response in terms of reduction in settling time, elimination of steady-state error and minimization of speed overshoot.

\subsection{Batteries}

Batteries in today's society are so prolific and easy to use that it is easy to dismiss the effect they have on convenience, comfort, and technological advancement. They have contributed to the development of the cell-phone industry, portable electronics and computing, robotics, and the electric car industry, 
just to name a few. Without the ability to store energy electrochemically in a battery, many of today's advancements would not be possible. [21]

We will focus primarily on the three most common types of batteries applied currently in modern vehicles. The above mentioned batteries are the lead-acid battery (PbAc), the nickel-metal hydride battery (NiMH), and the lithium-ion battery (Li-ion). [21]

The most common battery in current vehicles is the lead-acid battery. Lead-acid batteries have their benefits, and as a result, have been widely adopted for today's internal combustion engine (ICE) vehicles, for a specific purpose. Lead-acid batteries have a long shelf-life, they are inexpensive, reliable, easily recyclable, and they are safe when properly handled and maintained. The lead-acid battery provides the functions of starting, lighting, and igniting the vehicle's ICE, cabin, and lighting systems. [21]

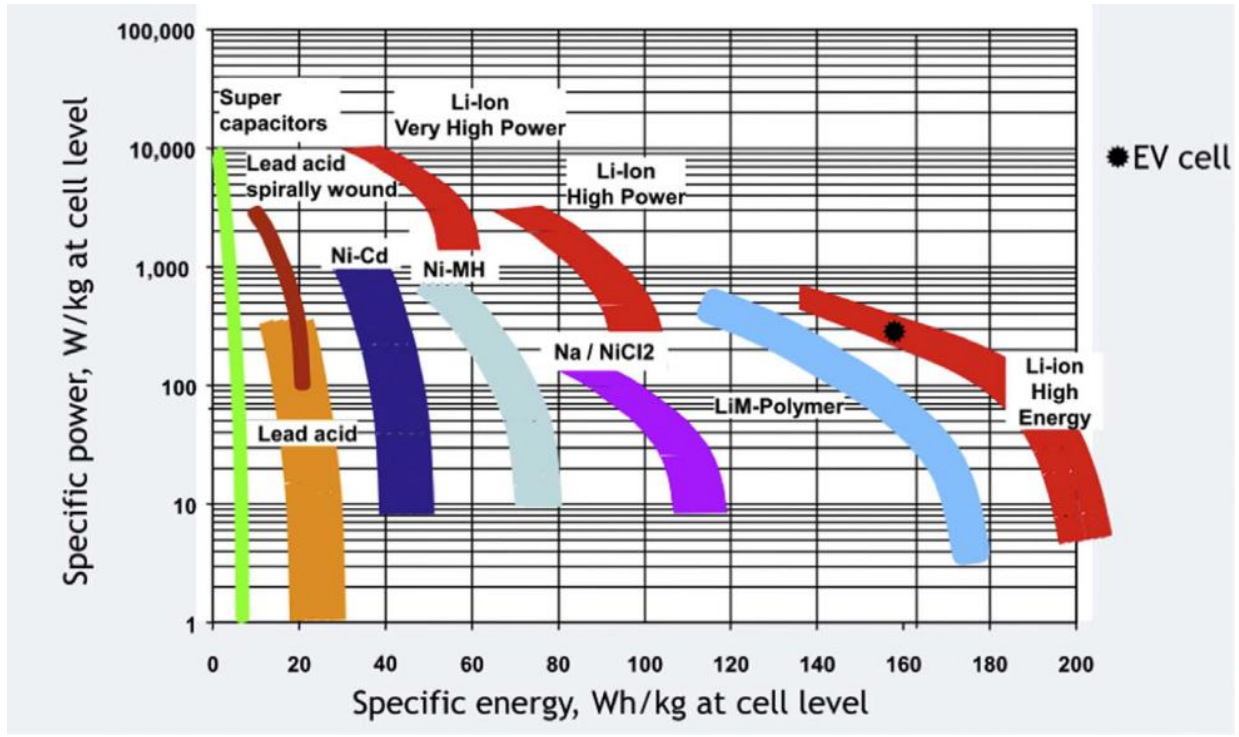

Figure 1. Specific energy and power of the main battery technologies. [22]

As seen in Figure 1, this technology has low specific energy, typically between 20 and $40 \mathrm{Wh} / \mathrm{kg}$. [23] A range of $200 \mathrm{~km}$ would necessitate about $150 \mathrm{~kg}$ of Lithium-ion batteries but more than $500 \mathrm{~kg}$ of lead acid cells with battery electric vehicles (BEV). This is why the lead acid battery is not being considered for use in future BEVs. [22]

The nickel-metal hydride (NiMH) battery was the next rechargeable battery widely produced for commercial applications in hybrid electric vehicles (HEV). The costs were around USD 700-800/kWh [22] and, therefore, less expensive than Li-ion batteries. Ni-MH battery technology is considered a mature technology, however, it has reached its best potential, both in cost-reduction and characteristics. As seen in Figure 1, its energy density is between 60 and $80 \mathrm{Wh} / \mathrm{kg}$ [22] and is considered insufficient for the needs of BEVs. [22] The NiMH battery is still being deployed today in HEVs and plug-in hybrid electric vehicles (PHEVs). PHEVs operate in the same manner as HEVs, however, they have the additional ability to plug into the electric grid to charge the battery. The NiMH batteries limited specific energy does constrain the electric-only range of HEVs and PHEVs. [21] 
The next step in the progression of battery technology and its implementation with relation to HEVs, and battery electric vehicles (BEVs or EVs) was the lithium-ion battery. The limiting factor for vehicles is size and weight, and as a result, the automotive industry constantly seeks a battery that has a greater specific energy and energy density to increase the range of electric vehicles, one of consumers biggest concerns regarding EVs. The Li-ion battery is a step in that direction. The Li-ion battery has a specific energy of over $200 \mathrm{Whkg}-1$, and an energy density of $250 \mathrm{Whl}-1$.

However, it is expensive (more than USD $700 / \mathrm{kWh}$ ), it presents safety issues (overcharging can cause fires and destruction) and the energy density is still insufficient to satisfy the needs of the market. There is a large variety of Lithium-ion chemistries, with different characteristics and degrees of maturity. [21, 22, 23]

Reference [24] presents an improved and easy-to-use battery dynamic model. The charge and the discharge dynamics of the battery model are validated experimentally with four batteries types.

Reference [25] presents a comprehensive review and evaluation of various types of electric vehicles and its associated equipment in a particular battery charger and charging station.

Reference $[26,27,28]$ represents the evaluation of ageing parameters in lithium iron phosphate based batteries, through investigating different current rates, working temperatures and depths of discharge. From these analyses, one can derive the impact of the working temperature on the battery performances over its lifetime.

An appropriate model of these batteries is fundamental for the simulation of several processes inside an EV, such as the state of charge (SoC) estimation, capacity and power fade analysis, lifetime calculus, or for developing control and optimization strategies. Reference [29] compares and contrasts the different electrical equivalent circuit models, impedance models, and runtime models for batterybased EV applications, addressing their characteristics, advantages, disadvantages, and usual applications in the field of electromobility.

\subsection{Fuel cells}

The basic principle of the fuel cell was discovered in the year 1838 by Swiss scientist Christian Friedrich Schönbein. In 1839 Sir William Grove developed the first fuel cell based on reversing the electrolysis of water by accident. A fuel cell is an energy conversion device that converts the chemical energy of a reaction directly into electricity with by-product of water and heat. The structure of a simplified fuel cell is shown in Figure 2. [30] 


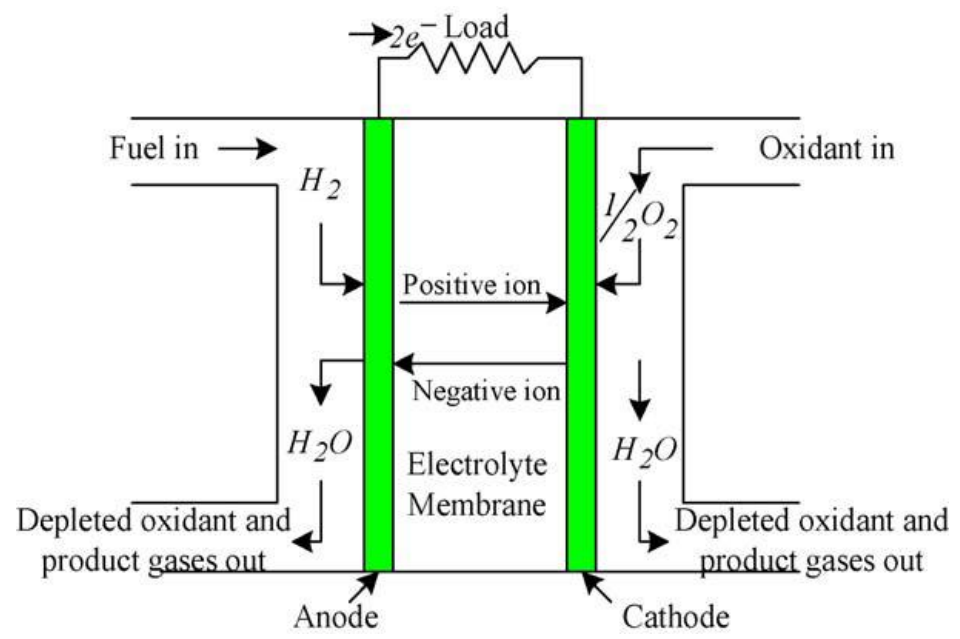

Figure 2. Fuel cell operation diagram. [30]

The fuel cell consists of an electrolyte layer in contact with two electrodes on either side. The hydrogen fuel is fed continuously to anode electrode and the oxidant (or) oxygen from air is fed continuously to the cathode electrode. At the anode terminal the hydrogen fuel is decomposed into positive ions and negative ions. The intermediate electrolyte membrane permits only the positive ions to flow from anode to cathode side and acts as an insulator for electrons. These electrons want to recombine on the other side of the membrane for the system to become stable, for which the free electrons move to the cathode side through an external electrical circuit. The recombination of the positive and negative ions with oxidant takes place at the cathode to form depleted oxidant (or) pure water. [30] The fuel cells are classified according to the choice of electrolyte and fuel. Presently, six major different types of fuel cells are available: [30, 31, 32]

- Proton exchange membrane fuel cell (PEMFC):

o Direct formic acid fuel cell (DFAFC);

o Direct Ethanol Fuel Cell (DEFC).

- Alkaline fuel cell (AFC):

o Proton ceramic fuel cell (PCFC);

o Direct borohydride fuel cell (DBFC).

- Phosphoric acid fuel cell (PAFC)

- Molten carbonate fuel cell (MCFC)

- Solid oxide fuel cell (SOFC)

- Direct methanol fuel cell (DMFC)

Polymer Exchange Membrane Fuel Cell: solid polymer membranes are used as the electrolyte in PEMFCs. The polymer membrane is perfluorosulfonic acid referred to as Nafion. This polymer membrane is acidic; hence, the ions transported are hydrogen ions or protons. The PEMFC is fuelled with pure hydrogen, and the oxidant is air or pure oxygen. PEMFCs are low temperature fuel cells that conduct hydrogen ions $(\mathrm{H}+)$, making them non fuel-flexible. These fuel cells are the most widely-used in the transportation sector because they are low temperature FCs, operating around $80{ }^{\circ} \mathrm{C}$, thus they have relatively short starting and stopping times. Another advantage to PEMFCs is that they have very high efficiency and power density in the vehicle engine size class. These features are well-suited to a 
vehicle power source where power density is desired and the dynamic power demands are significant. Some of the drawbacks to PEMFCs include a higher risk of CO poisoning and that they require cooling. $[30,31,32]$

The PEMFC in an electric vehicle is taking the role of the internal combustion engine in a HEV, as it is the driving power source in the FC electric vehicle. Thus far, the PEMFC is the only fuel cell found to be suitable for automobiles. By pairing PEMFCs with rechargeable batteries, a hybrid vehicle is created that is competitive with both battery electric and fossil fuel vehicles. The electric motor, the battery, and the PEMFC are the three interdependent parts of this hybrid vehicle. [32, 33, 34]

There are two primary options for all-electric vehicles: batteries or fuel cells. Reference [35] shows that for any vehicle range greater than $160 \mathrm{~km}$ (100 miles) fuel cells are superior to batteries in terms of mass, volume, cost, initial greenhouse gas reductions, refuelling time, well-to-wheels energy efficiency using natural gas or biomass as the source and life cycle costs.

References [36,37] present a novel approach to fuel cell modelling. The model is developed with the objective to facilitate the simulation of fuel-cell power systems and requires only few variables from manufacturer datasheets. These models are generic ones and able to emulate the behaviour of any fuel cell types fed with hydrogen and air.

Reference [38] investigates the modelling approach based on the Matlab SimPowerSystems Toolbox (SPS) of a fuel cell electric vehicle (FCEV). The objective of this approach is to increase the accurate modelling of the power source, the power converter and the load to evaluate the full system performances since the simulation step.

\section{Review of hybrid electric powertrains}

Since, HEVs combine the drive powers of an internal combustion engine and an electrical machine, first we must deal with modern internal combustion engines, and after that the modern hybrid systems.

\subsection{Modern internal combustion engines}

The internal combustion engine (ICE) is commonly used on a daily basis. It is of particular interest in transportation, and hence in the automobile industry. In 1876 the four-stroke cycle, as is known today, was introduced, in the form of the Otto gas engine. A further configuration should be mentioned in addition to this first one, specifically the one introduced by Diesel. His patent dates from 1893 and it was the result of 15 years of work. This engine required a long time to be developed, especially the injection system. While at present it is well known for its success in the automobile sector, the first realizations were dedicated to marine transportation, rail transportation, and also to industrial engines, before it came to conquer the markets of trucks and motor cars. At present, the abovementioned two types of engines are very similar. [39]

Piston engines or reciprocating engines (the two terms are often used interchangeably) are by a wide margin the largest group of thermodynamic heat engines in use around the world. The piston engines 
used for power generation are almost exclusively derived from similar engines designed for motive applications. Smaller units are normally based on car or truck engines, while larger engines are based on locomotive or marine engines. The performance of these engines varies. The small engines are usually cheap because they are mass-produced, but they have relatively low efficiency and short lives. Larger engines tend to be more expensive, but they will operate for much longer. Large, megawattscale engines are among the most efficient prime movers available, with simple cycle efficiencies approaching 50\%. [40]

Nowadays, major advances have been made, making today's internal combustion (IC) engine a technological marvel. However, recently, the reputation of IC engines has been dealt a severe blow by emission scandals that threaten the ability of this technology to make significant and further contributions to the reduction of transportation sector emissions. In response, there have been proposals to replace vehicle IC engines with electric-drives with the intended goals of reducing fuel consumption and emissions further, and to decrease vehicle greenhouse gas (GHG) emissions. Certainly, exploring new and competitive engine technologies, as well as new fuels, is important for a sustainable future for our planet. For the foreseeable future, road and off-road transport will be characterized by a mix of solutions involving internal combustion engines, battery and hybrid powertrains, as well as conventional vehicles powered by IC engines. [41]

The current science described in reference [42] suggests that there could be 6-15\% improvements in internal combustion fuel efficiency in the coming decade, although filters to meet emission legislation reduce these gains. Using these engines as hybrids with electric motors produces a reduction in energy requirements in a range of $21-28 \%$. [43, 44] Developments beyond the next decade are likely to be dominated by four topics: emission legislation and emission control, new fuels, improved combustion and a range of advanced concepts for energy saving. Of the new fuels, non-conventional fossil-derived fuels are associated with larger greenhouse gas emissions than conventional petroleum-based fuels, while a vehicle propelled by fuel cells consuming non-renewable hydrogen does not necessarily offer an improvement in emissions over the best hybrid internal combustion engines. Improved combustion may be developed for both gasoline and diesel fuels and promises better efficiency as well as lower noxious emissions without the need for filtering. Finally, four advanced concepts are considered: new thermodynamic cycles, a Rankine bottoming cycle, electric turbo-compounding and the use of thermoelectric devices. The latter three all have the common theme of trying to extract energy from waste heat, which represents about $30 \%$ of the energy input to an internal combustion engine.

In reference [45], a comprehensive review of the most common and compromising methods and technologies (turbocharged and supercharged, direct fuel injection, variable valve timing [46, 47], variable compression ratio, cooled exhaust gas recirculation, water injection [48], low temperature combustion, homogeneous charge compression ignition) that can be used to optimize the IC engines efficiency is represented.

References $[49,50]$ review various types of fuels including fossil fuels such as gasoline and diesel and also alternative fuels such as LPG, CNG, Hydrogen, Alcohol, Bio-diesel and P-series fuels. Advantages and disadvantages of each type of fuels in terms of economics, performances, and environments were discussed. 
The two major fuels that had been developed and widely used along with the development of the ICEs and the automotive industries over the past century are gasoline and diesel. The combustion of gasoline fuel undergoes flame propagation after an initial spark event igniting the homogeneous airfuel mixture in SI engines, while the combustion of diesel fuel is driven by the auto-ignition of the fuel exposed to high temperature gas, heated by compression in CI engines. Despite the long history of a steady supply chain and the determined position of gasoline and diesel as conventional automotive fuels in the market, the search for alternative fuels gradually started to emerge back in the 1980s. The definition of alternative fuels may vary depending on the context. Alternative fuels as those other than conventional gasoline and diesel fuels cover a wide variety in terms of final forms and manufacturing sources. For example, ethanol fuel is considered an alternative for SI engines, regardless of its original source from either conventional crude oil or any renewable biomass. Alternative fuels defined by the Energy Policy Act (EPAct) also cover a vast amount of non-conventional fuels, including alcohols, such as ethanol (including blends with gasoline over 85\%); natural gas and liquefied fuels domestically derived from natural gas; liquefied petroleum gas (LPG); coal-derived liquid fuels (CTL); hydrogen (H2) $[51,52,53]$; biodiesel (B100); fuels, other than alcohol, derived from biological materials; and fuel that is substantially non-petroleum that yields substantial energy security and environmental benefits.

Reference [54] analyses and compares two optimized solutions for a HEVs: a spark ignition Internal Combustion Engine (ICE) based one and Fuel Cell (FC) based one. A mathematical model to simulate the performance and the energy consumption of the two proposed solutions has been developed using the WLTP, US06, Highway and Urban driving cycles for the comparison.

References $[55,56,57,58]$ deal with thermodynamic modelling and simulation of internal combustion engines.

\subsection{Hybrid electric systems}

The rapid consumption of fossil fuel and increased environmental damage caused by it have given a strong impetus to the growth and development of fuel-efficient vehicles. Hybrid electric vehicles (HEVs) have evolved from their inchoate state and are proving to be a promising solution to the serious existential problem posed to the planet earth. Not only do HEVs provide better fuel economy and lower emissions satisfying environmental legislations, but also they dampen the effect of rising fuel prices on consumers. HEVs combine the drive powers of an internal combustion engine and an electrical machine. The main components of HEVs are energy storage system, motor, bidirectional converter and maximum power point trackers (MPPT, in case of solar-powered HEVs). The performance of HEVs greatly depends on these components and its architecture. In references [59, 60, $61,62,63,64]$ a general review of HEV technology is presented while references $[65,66,67,68,69,70$, $71,72,73$ ] deals with the simulation and analysis of HEVs and their components in MATLAB/Simulink environment.

In reference [59] an extensive review is presented on the essential components used in HEVs such as their architectures with advantages and disadvantages, choice of bidirectional converter to obtain high efficiency, combining ultracapacitor with battery to extend the battery life, traction motors' role and 
their suitability for a particular application. Inclusion of photovoltaic cell in HEVs is a fairly new concept and has been discussed in detail. Various MPPT techniques used for solar-driven HEVs are also discussed together with their suitability. In reference [60] the various drives used for the EVs \& HEVs are discussed. The main two types of drive, based on the used supply, DC or AC drive. The AC drives consisting of three phase permanent magnet synchronous motor (PMSM) is most popular amongst them. The other widely used drives are three phase Induction motor (IM), Switched reluctance motor (SRM) and Brushless DC motor (BLDC). These motors are fed by different power electronic converters such as DC-DC converter, DC- AC converters per the supply requirements. Reference [61] revises and reviews EMSs that are proposed and developed in the recent years. Additionally, the Plug-in HEV is discussed in a new perspective from the EMS point of view. The through-the-road (TtR) HEV within-wheel motors (IWM) is a fairly new concept in the HEV design that features less complicated configuration with reduced hardware requirements and lower cost. Recent research findings are evaluated throughout this reference leading to a hypothetical TtR HEV materialization. A thorough discussion is made encompassing the advantages and disadvantages of the concept, its performance compared to conventional HEVs and the way forward. In reference [62] various aspects and techniques of HEV from energy management system (EMS), power conditioning and propulsion system are explored. Other related fields of HEV such as DC machine and vehicle system are also included. Various type models and algorithms derived from simulation and experiment are explained in detail. The performances of the various combination of HEV system are summarized in table form along with relevant references. The paper provides comprehensive survey of hybrid electric vehicle on their source combination, models, energy management system (EMS) etc. developed by various researchers. From the rigorous review, it is observed that the existing technologies more or less can capable to perform HEV well; however, there liability and the intelligent systems are still not up to the mark. Accordingly, this review have been lighted many factors, challenges and problems sustainable next generation hybrid vehicle. In reference [63] the various architectures of HEV, different methodologies of hybrid vehicle, are focused. The design criteria and optimization techniques with reference to the driving cycle is also elucidated. The various electric drives used for HEV are also discussed. Additionally, the different electric propulsion systems are explained. Reference [64] aims at reviewing the history, the development, and the current scenario of hybrid electric vehicle (HEV). The paper goes in detail analyzing the origin of HEVs, their growth and debacle, the current stage of HEVs, and the social and economic impact it can have on the modern world. The paper also draws light on the future technologies that can be implemented in HEVs which can hence make Earth greener.

Reference [65] mainly focuses on modeling, simulation, and analysis of a parallel HEV to improve the fuel economy and reduce the overall emission, as well as enhancing the performance of the HEV by optimizing the efficiency of the battery pack. Moreover, technical considerations to minimize the mechanical and electrical power losses, as well as maximizing the energy absorption from the braking system, are investigated. ADVISOR, which is a MATLAB/Simulink-based software, is used for the simulation and analysis of the HEV. In reference [66] the series-parallel drivetrain architecture present in Hybrid Electric Vehicles is studied and modeled in detail using Matlab/Simulink. The system is composed of two permanent magnet synchronous machines in addition to the internal 
combustion engine all mechanically combined using a power split device. The novelty of this model is to use exclusively basic Simulink blocks resulting in a less execution time especially advantageous during implementation. Furthermore, the new modeling approach is focused on optimal control of both engine and electric machines in wide speed region. The obtained simulation results are proving the accuracy of the simpler dynamic model and the efficiency of its control. Reference [67] deals with parallel-hybrid electric vehicles and shows a modelling of electric and parallel-hybrid electric vehicle using Matlab/Simulink environment which allows us to access different aspects of the vehicle such as engine power, type and size of the battery or weight and to observe how changes can affect the performance and the distance travelled. The model was simulated in order to obtain the electric vehicle's autonomy. Through the use of a Geographic Information System together with a mathematic algorithm based on genetic algorithms the planning of charging stations was obtained, where the installation investment cost was minimized and the geographic distribution was improved in order to increase the quality of the service by improving reliability. In reference [68] a parallel HEV hybrid controller is developed in the MATLAB/Simulink environment. Using the driver commands, the battery state of charge and the engine map, a set of efficient rules has been developed to efficiently split the power between the engine and the motor. In thesis [69] a hybrid vehicle model is created in MATLAB and ADAMS to demonstrate its fuel economy improvement over a conventional vehicle system. The hybrid vehicle model utilizes the Honda IMA (Integrated Motor Assist) architecture, where the electric motor acts as a supplement to the engine torque. The motor unit also acts as a generator during regenerative braking to recover the otherwise lost kinetic energy. The powertrain components power output calculation and the control logic were modeled in MATLAB/Simulink, while the mechanical inertial components were modeled in ADAMS. Communication between MATLAB and ADAMS was established by ADAMS/Controls. In reference [70] a model for Hybrid electric vehicle power train has been constructed. The HEV model developed is based on the Honda Integrated Motor Assist power-train which is utilized by Honda in its all the HEVs. In order to check the accuracy of the developed MATLAB-SIMULINK HEV model, the simulation is carried out on two different standard international drive cycles (NYCC,WVU5), and the data is compared with the published data. Three major performance parameters are compared to validate the developed model: fuel consumed, energy regenerated and energy consumed. Reference [71] examines the various energy conservation tools and examines their strengths and weaknesses. Some energy storage systems are designed and modeled in MATLAB/Simulink. The necessary electrical circuits are included in the hybrid storage system. Lastly, it presents, model of the hybrid power system (such as the Battery-Superpacator). Reference [72] presents a research on the energy management system for a specific PHEV. The system configuration, analysis, model, control strategy, and simulation results are presented in detail. Recommendations on the directions and areas in which the further research in hybrid vehicle should be aligned are also be included. Reference [73] presents the modelling, design and power management of a hybrid energy storage system for a three wheeled light electric vehicle under Indian driving conditions. The hybrid energy storage system described in this paper is characterized by effective coupling of Li-ion battery (primary energy source) and ultracapacitor (auxiliary source) interfaced with an efficient bi-directional converter. A design methodology related to vehicle modelling, choice of motor rating, converter design, sizing of Li-ion battery and ultracapacitor pack for the Indian driving cycle are presented. An improved real-time power-split management control strategy is proposed for 
proper power flow control of the hybrid energy storage system under various operating modes. Simulations are carried out in MATLAB/Simulink environment to verify the effectiveness of the proposed control strategy with modelled system components of three-wheeled light electric vehicle. A downscaled experimental prototype is built to validate the power-split between hybrid energy storage systems.

\section{Summary}

In this publication, we have reviewed the drive systems of current modern vehicles and the types and characteristics of their major components. In the case of electric vehicles, we have reviewed in detail the types of electric motors used in modern drive systems, as well as the batteries providing the power source for these motors. In addition, we have summarized information on fuel cells, which can also provide power for electric motors, with particular reference to the types used in the automotive industry. Hybrid drive systems, which are becoming more common today, have also been reviewed and information on modern internal combustion engines has also been summarized. Based on this, we intend to develop models and simulations of the above-mentioned powertrains, which will help us to perform different driving dynamics simulations and to compare the performance and characteristics of these powertrains to each other.

\section{Acknowledgement}

"The research was financed by the Thematic Excellence Programme of the Ministry for Innovation and Technology in Hungary (ED_18-1-2019-0028), within the framework of the (Automotive Industry) thematic programme of the University of Debrecen."

\section{References}

[1] Swaraj Ravindra Jape, Archana Thosar, COMPARISON OF ELECTRIC MOTORS FOR ELECTRIC VEHICLE APPLICATION, International Journal of Research in Engineering and Technology, Volume: 06 Issue: 09, September, 2017

[2] Juan de Santiago, Hans Bernhoff, Boel Ekergård, Sandra Eriksson, Senad Ferhatovic, Rafael Waters, Student Member, IEEE, and Mats Leijon, Member, IEEE, Electrical Motor Drivelines in Commercial All-Electric Vehicles: A Review, IEEE TRANSACTIONS ON VEHICULAR TECHNOLOGY, VOL. 61, NO. 2, FEBRUARY 2012

[3] Sen Li, A Review of Electric Motor Drives for Applications in Electric and Hybrid Vehicles, Technical Report, March 2017

[4] Hearn, C. S., Weeks, D. A., Thompson, R. C., \& Chen, D. (2010). Electric vehicle modeling utilizing DC motor equations. 2010 IEEE/ASME International Conference on Advanced Intelligent Mechatronics. doi:10.1109/aim.2010.5695785 
International Journal of Engineering and Management Sciences (IJEMS) Vol. 5. (2020). No. 2

DOI: 10.21791/IJEMS.2020.2.29.

[5] Miralem HADŽISELIMOVIĆ, Matic BLAZNIK, Bojan ŠTUMBERGER, Ivan ZAGRADIŠNIK, Magnetically Nonlinear Dynamic Model of a Series Wound DC Mot or, PRZEGLĄD ELEKTROTECHNICZNY (Electrical Review), ISSN 0033-2097, R. 87 NR 12b/2011

[6] Bitar, Z., Jabi, S. A., \& Khamis, I. (2014). Modeling and Simulation of Series DC Motors in Electric Car. Energy Procedia, 50, 460-470. doi:10.1016/j.egypro.2014.06.056

[7] Miss Avanti B.Tayade, Modeling and Simulation of A Bldc Motor By Using Matlab/Simulation Tool, Journal of Electrical and Electronics Engineering, e-ISSN : 2278-1676, p-ISSN : 2320-3331, PP 55-62.

[8] C. Gencer and M. Gedikpinar, 2006. Modeling and Simulation of BLDCM Using MATLAB/SIMULINK, Journal of Applied Sciences, 6: 688-691.

[9] Vikramarajan Jambulingam, Mathematical Modelling and Simulation of Brushless DC Motor Using MATLAB, International Journal for Research in Applied Science \& Engineering Technology (IJRASET), Volume 3 Issue XII, December 2015 IC Value: 13.98 ISSN: 2321-9653.

[10] Yong Zhou, Hong-kai Jiang, Qi-xun Zhou and Qing-jiang Zhang, A Novel Method for Modeling and Simulation of Brushless DC Motor with Kalman Filter, Advanced Technology in Teaching, AISC 163, pp. 305-314., springerlink.com (c) Springer-Verlag Berlin Heidelberg 2012.

[11] Mohan, N. (2014). Advanced Electric Drives: Analysis, Control, and Modeling Using MATLAB/Simulink. Wiley Blackwell. https://doi.org/10.1002/9781118910962

[12] Shi, K. L., Chan, T. F., Wong, Y. K., \& Ho, S. L. (1999). Modelling and Simulation of the Three-Phase Induction Motor Using Simulink. International Journal of Electrical Engineering Education, 36(2), 163-172. doi:10.7227/ijeee.36.2.6

[13] Adel Aktaibi, Daw Ghanim, M. A. Rahman, Dynamic Simulation of a Three-Phase Induction Motor Using Matlab Simulink, Book of the 20th Annual Newfoundland Electrical and Computer Eng. Conference (NECEC 2011), IEEE, November 2011, DOI: 10.13140/RG.2.1.2705.4243

[14] Adhavan Balashanmugham and Mockaisamy Maheswaran, Permanent-Magnet Synchronous Machine Drives, open access peer-reviewed chapter, September 2019, DOI: 10.5772

[15] H. M. El Shewy, F. E. Abd Al Kader, M. M. El Kholy, A. El Shahat, Dynamic modeling of permanent magnet synchronous motor using MATLAB - simulink, Proceedings of the 6 th ICEENG Conference, 27-29 May, 2008.

[16] Sabrina K. Rechkemmer, Weimin Zhang, Oliver Sawodny, Modeling of a Permanent Magnet Synchronous Motor of an E-Scooter for Simulation with Battery Aging Model, IFAC PapersOnLINE 50-1, 4769-4774, 2017

[17] Wach, P. (2011). Dynamics and Control of Electrical Drives. doi:10.1007/978-3-642-20222-3

[18] Vikramarajan Jambulingam, Mathematical Modeling and Simulation of Switched Reluctance Motor, International Journal for Research in Applied Science \& Engineering Technology (IJRASET), Volume 4 Issue IV, April 2016, ISSN: 2321-9653 
[19] Nikolay Grebennikov and Alexander Lebedev, 2016. Development of Switched Reluctance Machines Model in MATLAB/Simulink. Journal of Engineering and Applied Sciences, 11: 14341438.

[20] A.E. Anyalebechi, SIMULATION OF SPEED CONTROL TECHNIQUES OF SWITCHED RELUCTANCE MOTORS (SRM), International Research Journal of Engineering and Technology (IRJET), Volume: 05 Issue: 12, Dec 2018 e-ISSN: 2395-0056, p-ISSN: 2395-0072

[21] Ryan Sprague: An Analysis of Current Battery Technology and Electric Vehicles. Journal of Undergraduate Research 5, 1 (2015)

[22] Amin Mahmoudzadeh Andwaria, Apostolos Pesiridisa, Srithar Rajooc, Ricardo Martinez-Botasd, Vahid Esfahanianb: A review of Battery Electric Vehicle technology and readiness levels. Elsevier: Renewable and Sustainable Energy Reviews 78 (2017) 414-430. http://dx.doi.org/10.1016/j.rser.2017.03.138

[23] Miller JM. Energy storage system technology challenges facing strong hybrid, plug-in and battery electric vehicles. Veh Power Propuls Conference 2009. VPPC '09. IEEE; 2009. p. 4-10. http://dx.doi.org/10.1109/VPPC.2009.5289879.

[24] Olivier Tremblay1, Louis-A. Dessaint: Experimental Validation of a Battery Dynamic Model for EV Applications. EVS24 Stavanger, Norway, May 13 - 16, 2009. World Electric Vehicle Journal Vol. 3 - ISSN 2032-6653 - (C) 2009 AVERE

[25] Afida Ayob, Wan Mohd Faizal Wan Mahmood, Azah Mohamed et al.: Review on Electric Vehicle, Battery Charger, Charging Station and Standards. Research Journal of Applied Sciences, Engineering and Technology 7(2): 364-373, 2014. DOI:10.19026/rjaset.7.263 ISSN: 2040-7459; e-ISSN: 2040-7467 @ 2014 Maxwell Scientific Publication Corp.

[26] Cong Zhu, Xinghu Li, Lingjun Song, Liming Xiang: Development of a theoretically based thermal model for lithium ion battery pack. Journal of Power Sources 223 (2013) 155e164. Elsevier. http://dx.doi.org/10.1016/j.jpowsour.2012.09.035

[27] Noshin Omar, Mohamed Abdel Monema, Yousef Firouz et al.: Lithium iron phosphate based battery - Assessment of the aging parameters and development of cycle life model. Applied Energy 113 (2014) 1575-1585 Elsevier. http://dx.doi.org/10.1016/j.apenergy.2013.09.003

[28] L.H. Saw, K. Somasundaram, Y. Ye, A.A.O. Tay: Electro-thermal analysis of Lithium Iron Phosphate battery for electric vehicles. Journal of Power Sources 249 (2014) 231e238. Elsevier. http://dx.doi.org/10.1016/j.jpowsour.2013.10.052

[29] Gaizka Saldaña, José Ignacio SanMartín et al.: Analysis of the Current Electric Battery Models for Electric Vehicle Simulation. Energies 2019, 12, 2750; doi:10.3390/en12142750

[30] A. Kirubakaran, Shailendra Jain, R.K. Nema: A review on fuel cell technologies and power electronic interface. Renewable and Sustainable Energy Reviews 13 (2009) 2430-2440. Elsevier. doi:10.1016/j.rser.2009.04.004 
[31] Pratik Ranjan Behera, Ritesh Dash, S.M Ali, Kunjan Kumar Mohapatra: A review on fuel cell and its applications. IJRET: International Journal of Research in Engineering and Technology eISSN: 2319-1163 | pISSN: 2321-7308. Volume: 03 Issue: 03 | Mar-2014

[32] Yogesh Manoharan, Seyed Ehsan Hosseini, Brayden Butler et al.: Hydrogen Fuel Cell Vehicles; Current Status and Future Prospect. Appl. Sci. 2019, 9, 2296; doi:10.3390/app9112296

[33] I. Zamora, J.I. San Martín et al.: PEM Fuel Cells in Applications of Urban Public Transport. International Conference on Renewable Energies and Power Quality (ICREPQ'11). https://doi.org/10.24084/repqj09.399 RE\&PQJ, Vol.1, No.9, May 2011

[34] Himadry Shekhar Das, Chee Wei Tan, A.H.M. Yatim: Fuel cell hybrid electric vehicles: A review on power conditioning units and topologies. Renewable and Sustainable Energy Reviews 76 (2017) 268-291 http://dx.doi.org/10.1016/j.rser.2017.03.056

[35] C.E. Thomas: Fuel cell and battery electric vehicles compared. 2009. International Association for Hydrogen Energy. Published by Elsevier Ltd. All rights reserved. doi:10.1016/j.ijhydene.2009.06.003

[36] Souleman Njoya M., Olivier Tremblay, et al.: A Generic Fuel Cell Model for the Simulation of Fuel Cell Vehicles. 978-1-4244-2601-0/09/\$25.00 (C2009 IEEE

[37] Souleman Njoya Motapon, Olivier Tremblay, Louis-A. Dessaint: Development of a generic fuel cell model: application to a fuel cell vehicle simulation. Int. J. Power Electronics, Vol. 4, No. 6, 2012. Inderscience Enterprises Ltd.

[38] N. Benyahia, H. Denoun, M. Zaouia, T. Rekioua, N. Benamrouche: Power system simulation of fuel cell and supercapacitor based electric vehicle using an interleaving technique. http://dx.doi.org/10.1016/j.ijhydene.2015.03.08 10360-3199/Copyright (C) 2015, Hydrogen Energy Publications, LLC. Published by Elsevier Ltd.

[39] Michel Feidt: Finite Physical Dimensions Optimal Thermodynamics 1. 2017. 99-124.p. Hardcover ISBN: 9781785482328. eBook ISBN: 9780081023495, Elsevier.

[40] Paul Breeze: Power Generation Technologies, 2nd Edition. 2014. Elsevier. 93-110.p. eBook ISBN: 9780080983363. Paperback ISBN: 9780080983301

[41] R D Reitz et al.: The future of the internal combustion engine. International J of Engine Research 2020, Vol. 21(1) 3-10. https://doi.org/10.1177/1468087419877990

[42] Alex M.K.P. Taylor: Science review of internal combustion engines. 2008 Queen's Printer and Controller of HMSO. Published by Elsevier Ltd. doi:10.1016/j.enpol.2008.09.001

[43] Teresa Donateo: Intelligent Usage of Internal Combustion Engines in Hybrid Electric Vehicles. 2012. doi: $10.5772 / 48120$

[44] Daniel S. Cardoso, Paulo O. Fael, António Espírito-Santo: A review of micro and mild hybrid systems. ICEER 2019. https://doi.org/10.1016/j.egyr.2019.08.077 
[45] Noureddine Guellouh, Zoltán Szamosi, Zoltán Simenfalvi: Review of improvement methods of internal combustion engine efficiency. 2019. doi: 10.26649/musci.2019.040

[46] H. Hong, G. B. Parvate-Patil, B. Gordon: Review and analysis of variable valve timing strategieseight ways to approach. IMechE 2004. Proc. Instn Mech. Engrs Vol. 218 Part D: J. Automobile Engineering

[47] Aniruddha Joshi et al.: A review study on variable valve timing systems. International Journal of Innovations in Engineering Research and Technology [IJIERT], ISSN: 2394-3696, 2018.

[48] Sipeng Zhu et al.: A review of water injection applied on the internal combustion engine. Energy $\begin{array}{lllll}\text { Conversion } \quad \text { and } & \text { Management }\end{array}$ https://doi.org/10.1016/j.enconman.2019.01.042. Elsevier.

[49] Choongsik Bae, Jaeheun Kim: Alternative fuels for internal combustion engines. Proceedings of the Combustion Institute $36 \quad$ (2017) 3389-3413. Elsevier. http://dx.doi.org/10.1016/j.proci.2016.09.009

[50] M. Faizal, M. H. Hamzah, A. Navaretsnasinggam: Review of fuels for internal combustion engines in the aspect of economy, performance, environment and sustainability. 2009. https://www.researchgate.net/publication/263874565

[51] M. Faizal et al.: Review of hydrogen fuel for internal combustion engines. Journal of Mechanical Engineering Research and Developments (JMERD) 42(3) (2019) 35-46. http://doi.org/10.26480/jmerd.03.2019.35.46

[52] Ho Lung Yip et al.: A Review of Hydrogen Direct Injection for Internal Combustion Engines: Towards Carbon-Free Combustion. Appl. Sci. 2019, 9, 4842; doi:10.3390/app9224842

[53] Hüseyin Turan Arat: Alternative fuelled hybrid electric vehicle (AF-HEV) with hydrogen enriched internal combustion engine. https://doi.org/10.1016/j.ijhydene.2018.12.2192019. Hydrogen Energy Publications LLC. Published by Elsevier Ltd.

[54] Paolo Di Giorgio et al.: Model based preliminary design and optimization of Internal Combustion Engine and Fuel Cell hybrid electric vehicle. 2018. Energy Procedia 148. 1191-1198.

[55] David Buttsworth: Multizone Internal Combustion Engine Modelling: Initial assessment of a Simulation Tool Developed in Matlab. 978-1-4244-5145-6/09/\$26.00 (C2009 IEEE

[56] Olivier Grondin et al.: Modelling the Compression Ignition Engine for Control: Review and Future Trends. 2004 Society of Automotive Engineers, Inc. DOI: 10.4271/2004-01-0423

[57] M. Thomhill et al.: A real-time simulation of an internal combustion engine. 1996 IFAC 8b-032 13th Triennial World Congress, San Francisco, USA

[58] Tianyu Zhu et al.: Simulation of the Original Injection MAP Diagram of Electronic-Controlled Gasoline Engines Based on MATLAB/SIMULINK. 978-1-4244-8165-1/11/\$26.00 (C2011 IEEE 
[59] Krishna Veer Singh, Hari Om Bansal, Dheerendra Singh: A comprehensive review on hybrid electric vehicles: architectures and components. J. Mod. Transport. (2019) 27(2):77-107 https://doi.org/10.1007/s40534-019-0184-3

[60] Mr. Anurag M. Lulhe, Mrs. Tanuja N.Oate: A Technology Review Paper for Drives used in Electrical Vehicle (EV) \& Hybrid Electrical Vehicles (HEV). 978-1-4673-9825-1/15/\$31.00 (C)2015 IEEE

[61] M.F.M. Sabri, K.A. Danapalasingam, M.F. Rahmat: A review on hybrid electric vehicles architecture and energy management strategies. Renewable and Sustainable Energy Reviews 53 (2016) 1433-1442. http://dx.doi.org/10.1016/j.rser.2015.09.036

[62] M.A. Hannan, F.A. Azidin, A. Mohamed: Hybrid electric vehicles and their challenges: A review. Renewable and Sustainable Energy Reviews 29 (2014) 135-150. http://dx.doi.org/10.1016/j.rser.2013.08.097

[63] V. Krithika, C. Subramani: A comprehensive review on choice of hybrid vehicles and power converters, control strategies for hybrid electric vehicles. Int J Energy Res. 2017;1-24. DOI: 10.1002/er.3952

[64] C. Parag Jose, S. Meikandasivam: A Review on the Trends and Developments in Hybrid Electric Vehicles. Innovative Design and Development Practices in Aerospace and Automotive Engineering, Lecture Notes in Mechanical Engineering, DOI 10.1007/978-981-10-1771-1_25. 2017

[65] Fazel Mohammadi et.al.: Modeling, Simulation, and Analysis of Hybrid Electric Vehicle Using MATLAB/Simulink. Proc, of the 5th International Conference on Power Generation Systems and Renewable Energy Technologies (PGSRET) 26-27 August, Turkey

[66] Moudrik Meradji et.al.: Dynamic Modeling and Optimal Control for Hybrid Electric Vehicle Drivetrain. 2016 IEEE International Conference on Industrial Technology (ICIT) DOI: 10.1109/ICIT.2016.7474967

[67] Susana Alegre et.al.: Modelling of electric and parallel-hybrid electric vehicle using Matlab/Simulink environment and planning of charging stations through a geographic information system and genetic algorithms. Renewable and Sustainable Energy Reviews 74 (2017) 1020-1027. http://dx.doi.org/10.1016/j.rser.2017.03.041

[68] Boukehili Adel et.al.: Parallel HEV Hybrid Controller Modeling for Power Management. World Electric Vehicle Journal Vol. 4 - ISSN 2032-6653 - (C) 2010 WEVA

[69] Brian Su-Ming Fan: Modeling and Simulation of A Hybrid Electric Vehicle Using MATLAB/Simulink and ADAMS. A thesis presented to the University of Waterloo in fulfillment of the thesis requirement for the degree of Master of Applied Science in Mechanical Engineering. Waterloo, Ontario, Canada, 2007 
International Journal of Engineering and Management Sciences (IJEMS) Vol. 5. (2020). No. 2

DOI: 10.21791/IJEMS.2020.2.29.

[70] MANAZIR AHMED KHAN: MODELING AND SIMULATION OF HYBRID ELECTRIC VEHICLE. International Journal of Mechanical and Production Engineering, ISSN: 2320-2092, Volume- 1, Issue- 3, Sept-2013

[71] Geetha Reddy Evuri et.al.: Simulation of Hybrid Electric Energy Storage System (HESS) for Hybrid Electric Vehicle for Power Applications. International Journal of Recent Technology and Engineering (IJRTE) ISSN: 2277-3878, Volume-7, Issue-5S3, February 2019

[72] Salisa Abdul Rahman et.al.: Optimal Energy Management for Plug-In Hybrid Electric Vehicles. Proceedings of the 3rd International Conference on Mechatronics, ICOM'08 18 - 20 December 2008, Kuala Lumpur, Malaysia

[73] S Devi Vidhya, M Balaji: Modelling, design and control of a light electric vehicle with hybrid energy storage system for Indian driving cycle. Measurement and Control 1-14. 2019. DOI: $10.1177 / 0020294019858212$ 